\title{
Diversity of Perceptions on REDD+ Implementation at the Agriculture Frontier in Panama
}

\author{
Guillaume Peterson St-Laurent, ${ }^{1,2,3}$ Nancy Gélinas, ${ }^{4}$ and Catherine Potvin ${ }^{1,2,3}$ \\ ${ }^{1}$ Department of Biology, McGill University, 1205 Doctor Penfield Avenue, Montreal, QC, Canada H3A 1B1 \\ ${ }^{2}$ Smithsonian Tropical Research Institute (STRI), Apartado 0843-03092, Balboa, Ancon, Panama \\ ${ }^{3}$ Centre D’étude de la Forêt, Case Postale 8888, Succursale Centre-Ville, Montréal, QC, Canada H3C 3P8 \\ ${ }^{4}$ Faculté de Foresterie, de Géographie et de Géomatique, Université Laval, Québec, QC, Canada G1K 7P4 \\ Correspondence should be addressed to Guillaume Peterson St-Laurent; guillaume.petersonst-laurent@mail.mcgill.ca
}

Received 30 July 2012; Accepted 21 December 2012

Academic Editor: Damase Khasa

Copyright (C) 2013 Guillaume Peterson St-Laurent et al. This is an open access article distributed under the Creative Commons Attribution License, which permits unrestricted use, distribution, and reproduction in any medium, provided the original work is properly cited.

Colonist farmers have been largely ignored to date in national consultations on reducing emissions from deforestation and forest degradation (REDD+). Yet, good practices suggest that understanding all relevant stakeholders' perspectives, goals, and issues is a precondition for the development of successful environmental policies. The present research documents perceptions of the civil society and the government on the possibility of successfully implementing REDD+ activities with colonist farmers. The focus is on Eastern Panama. The perceptions on REDD+ vary greatly depending on the stakeholders' origins. The government perceives REDD+ as a possibility for improving laws, increasing control over the national territory, and investing more resources for conservation and public institutions, whereas respondents from colonist backgrounds mostly insist on the potential economic benefits and/or the negative implications that could encompass REDD+. Noncolonist participants from regional, national, and international organizations instead try to balance concerns of communities and conservation objectives. Because one of our results highlighted the difficulty of colonist farmers in speaking as a united voice, we carried out a case study of a successful colonists association in order to identify the characteristics and practices found to facilitate communal organization.

\section{Introduction}

Panama is a pilot country in the UN REDD Programme (UNREDD) and the Forest Carbon Partnership Facility (FCPF) of the World Bank, which have respectively allocated US $\$ 5.3$ and US $\$ 3.6$ million for its preparations in reducing emissions from deforestation and forest degradation (REDD+) $[1,2]$. The National Focal Point of REDD+ readiness in Panama is the National Environment Authority (ANAM). In the country, more than $50 \%$ of the primary forest overlaps indigenous territories [3], making indigenous people (IP) an important stakeholder group for REDD+. A special section of the Joint Program Document of the UN Collaborative Program addresses the consultation and participation of IP in REDD+ readiness. According to this document, REDD+ readiness would mainly be undertaken through a partnership with the National Coordinator of Indigenous Peoples of Panama
(COONAPIP), an organization that has been described as a "key actor and facilitator of the REDD program [4]." Other local actors, such as small-scale timber loggers, AfroPanamanians (descendants of African slaves), and colonist farmers (the term used to describe migrants to the agriculture frontier), have been apparently disregarded for the most part until now by UN-REDD and FCPF.

Due to concerns over negative socioeconomic consequences of REDD+ implementation, the international community has called attention to the requirements for free, prior, and informed consent (FPIC) (defined as "the establishment of conditions under which people exercise their fundamental right to negotiate the terms of externally imposed policies, programs, and activities that directly affect their livelihoods or wellbeing and to give or withhold their consent to them [5]") of all relevant local REDD+ actors. Participatory processes and community engagement are important ways by 
which FPIC can be met [6] and are likely to influence the equity and success of REDD+ projects [7]. Therefore, "local users should be given authority, information, and support to determine whether they engage with REDD+ or not [8]." Here, we argue that it would be most useful to consider colonist farmers in REDD+ strategy consultations, since they are believed to account for much of the deforestation in the country [4, 9-11].

Agriculture frontier colonization, typically achieved under the "colonist system," is initiated by modest farmers or landless individuals that, motivated by the possibility of owning land and encountering new opportunities, leave their region of origin in search for national land [12]. The Panamanian Agrarian Code permits any individual to settle on national land if they can justify its "functional use" [13], which often translates to deforestation [4]. The first farmers to arrive practice subsistence slash-and-burn agriculture for a few years until reduced soil fertility and lack of resources lead them to sell their land and continue further into the agriculture frontier in search of new territory. The buyers are often farmers with better financial capacity who aspire to practice extensive cattle ranching, the activity that is considered the most important driver of deforestation in Panama $[9,11,14]$. For the purpose of this paper, colonist farmers refer to settlers of humble origins, who permanently migrated to the frontier and depend upon the land for their survival, thereby excluding entrepreneurs living outside of the frontier (i.e., the "buyers").

This paper is part of a broader study that aims to understand the perceptions, aspirations, and land use activities of IP and colonist farmers, together with their interactions, to better inform possible REDD+ strategies in Panama and other countries where these two groups coexist. In this context, we have already documented the land use activities, perceptions, needs, and aspirations of individual colonist farmers in different areas of Eastern Panama [15]. Briefly, our results suggested that REDD+ initiatives in Eastern Panama need to take into account colonist farmers' land use preferences, culture, technical knowledge, and forest dependency as well as the inequalities and forest shortages found in the region. Here, we document how actors from the government, international aid agencies, regional and national nongovernmental organizations (including both NGOs and Panama's academics), and local colonist organizations from Eastern Panama perceive colonist farmers. These different organizations were selected because of their potential different relationships and standpoints with the colonist farmers, and since they will likely play a role in the elaboration and eventual implementation of a REDD+ strategy [16].

\section{Methodology}

2.1. Eastern Panama. Eastern Panama (Figure 1), which is often seen as the least important agricultural frontier in the country, faced its most important phase of forest colonization within the last 40 years with the construction of the Pan-American Highway [10, 12, 13, 17]. Between 1992 and 2000, the two eastern provinces of Panama have shown some of the highest annual deforestation rates in the country
(Panama, $-1.53 \% \mathrm{y}^{-1}$; Darien, $-1.74 \% \mathrm{y}^{-1}$; national average, $-1.12 \% \mathrm{y}^{-1}$ ) [18]. Therefore, halting further deforestation in these regions is crucial for future REDD+ implementation [4]. There are five principal ethnic groups in the region: Guna, Wounaan and Embera (IP), Afro-Panamanians, and colonist farmers. IP and Afro-Panamanians, respectively, account for $13.5 \%$ and $6.55 \%$ of Chepo, the eastern district of the province of Panama, and for $32.4 \%$ and $16.67 \%$ of the province of Darien [19]. The rest of the population consists mainly of colonist farmers.

2.2. Data Collection. Data collection was separated into three phases. During phase one (September and October 2010), the Knowledge Centre for Conflict Resolution in the Americas and the Caribbean (known by its Spanish acronym "CERCA"), which is a Panama-based NGO that specializes in conflict resolution, developed three three-day training workshops on alternative methods of conflict resolution, such as mediation, which were aimed at governmental institutions, indigenous people, and colonist organizations. At the agriculture frontier, territorial conflicts are ever present and have been major obstacles for governing forests. Tensions that were generated by colonist encroachment on IP territories in Eastern Panama had been observed as early as at the end of 1980 [20]. The conflict resolution workshops proposed possible solutions for preventing existing territorial conflicts from impeding future REDD+ implementation in Panama. We assisted in the workshops that were directed, respectively, at the government and colonist sectors, and which were attended by about 60 civil servants from some 20 governmental institutions and 30 representatives from different associations working with colonists. Participants belonged to institutions that were working at the national, regional, and local levels and, thus, represented diverse standpoints. Round tables that were carried out during both events sought to identify the potential key actors for the future implementation of REDD+ at the agriculture frontier. Furthermore, results from focus groups that were held during the third day concerning future REDD+ implementation were used to discuss important issues such as pilot projects, organizational capacity, role of the government, and barriers to REDD+. Participation during these workshops also provided a unique opportunity to establish contact with the participants of the present study.

Phase two included twenty-nine individual, semistructured interviews (October 2010-October 2011) that were conducted in Spanish by the main author of this paper with representatives of the local/regional government as well as local colonist, regional, national, and international organizations (Table 1). We acknowledge that our small sample size, which is due mainly to the lack of available experts in some sectors (e.g., international organizations), represents a limitation. We used a guide consisting of twenty-eight openended questions to get a sense of participants' opinions of (i) the main land use activities, drivers of deforestation, and land use situation of colonist territories; (ii) the vision of colonists regarding forests and conservation; (iii) the potential opportunities for, and barriers to, REDD+ implementation in colonist territory; and (iv) the capacity of colonists to 


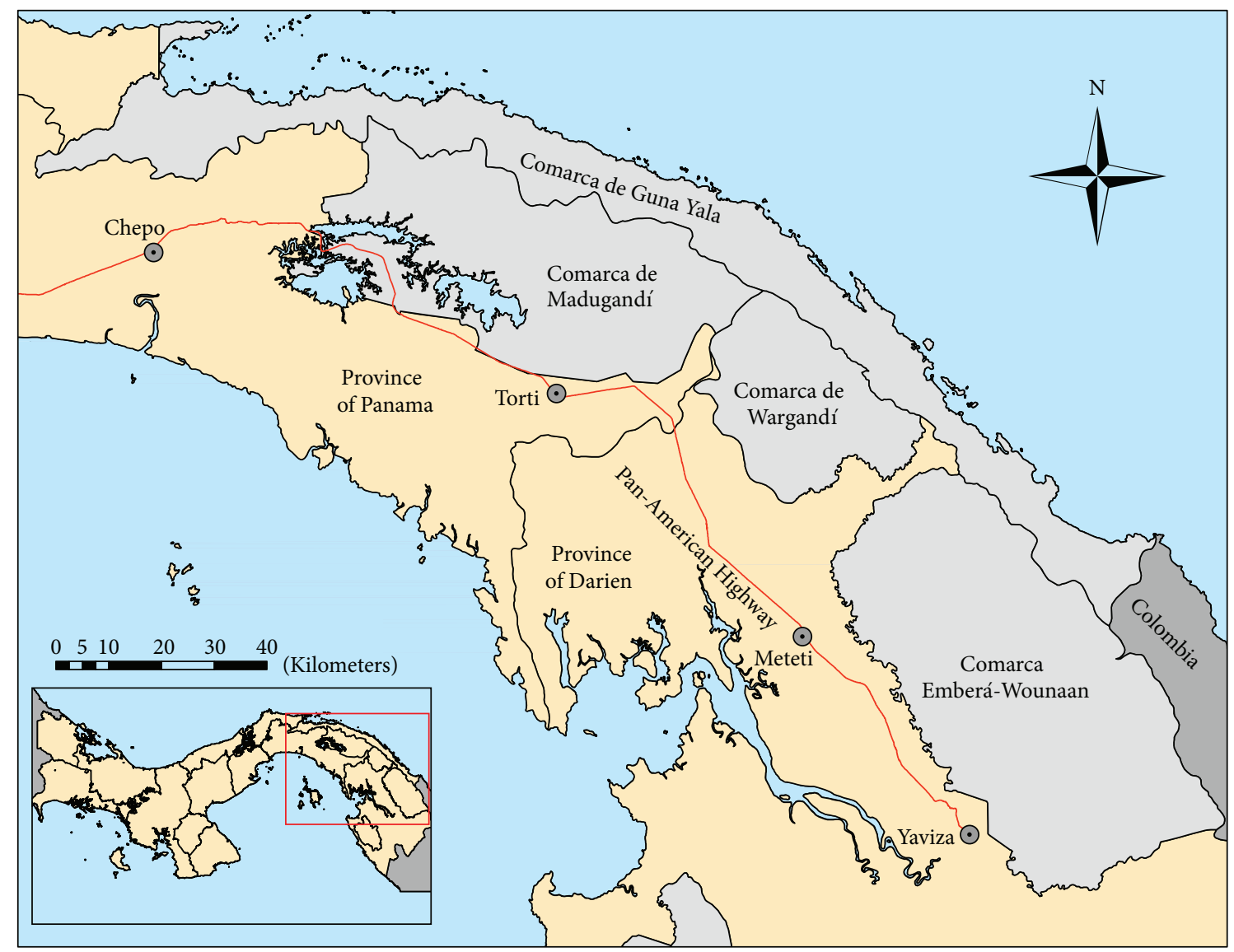

Figure 1: Map showing Eastern Panama, which includes the eastern part of the Province of Panama, starting in Chepo, a town that is located about $60 \mathrm{~km}$ east of Panama City, and the Province of Darien.

organize themselves into groups with common interests. The use of open-ended questions permitted us to create a context where in-depth discussions were not restricted by questions that were too specific or constrained $[21,22]$. Respondents were selected according to their connection, involvement, and knowledge of the colonist population of Eastern Panama and/or their potential role in the future implementation of a REDD+ program. During the interviews, no emphasis was given to the actual REDD+ readiness process in Panama to avoid discussing technicalities and to stay focused on perceptions of the colonist context, although interviews began with a presentation of REDD+ to bring the knowledge of the respondents to a common level. Some interviewees, however, already possessed previous knowledge of REDD+ (e.g., international aid organizations). Therefore, variation in the level of awareness among respondents is believed to have affected perceptions and comments.

During phase three, we carried out a detailed study of an organized colonist association (OCA; the true name of the association was kept confidential) in Darien Province to investigate the viability, promises, obstacles, and interest in participating in REDD+ and establishing pilot initiatives within organizations of colonists. OCA was not part of the local colonist organizations that we had contacted from the semistructured interviews. It diverges from most other local colonist organizations in that its members have a fairly good knowledge of REDD+ and because they have devoted themselves exclusively to sustainable practices. The association, which currently consists of ten active members, is considered by its funding organization to be one of the most successful in Darien. Three women and seven men created OCA in the 2000s, and the association was later legally recognized. The association had stemmed from the desire of its members to undertake common projects, conserve natural resources, and adopt sustainable cattle ranching practices. The group received its first funding ( $>20,000$ USD) two years after receiving legal status for a silvopastoral project. The results fulfilled the main requirements, and the group received a second grant (>25,000 USD) for another project that was linked with farm productivity and the details of which have been excluded to preserve anonymity. An understanding of the perceptions of successful local associations is of crucial importance, since they "may be [a] key structure through which REDD+ activities are managed, including the sharing of financial benefits [23]." To further inform the OCA members about REDD+, we organized a one-day workshop (eight participants; October 2011). A three-hour presentation of climate change and REDD+ was followed by a two-and-a-half hour discussion on the general understanding and perceptions of REDD+. Following this 
TABLE 1: Organizations that were interviewed during phase two.

\begin{tabular}{|c|c|c|}
\hline Group & Number of interviews & Name \\
\hline \multirow{6}{*}{ Local/regional government } & \multirow{6}{*}{ 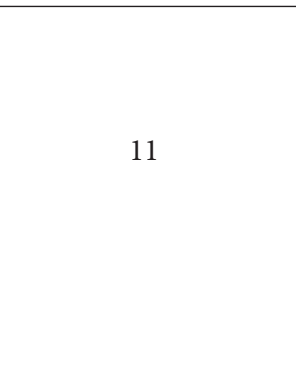 } & $\begin{array}{l}\text { (i) National Environmental Authority's (ANAM) regional technicians and/or } \\
\text { administrators (3) }\end{array}$ \\
\hline & & $\begin{array}{l}\text { (ii) Ministry of Agricultural Development's (MIDA) regional technicians and/or } \\
\text { administrators (2) }\end{array}$ \\
\hline & & (iii) Local government (2) \\
\hline & & (iv) Governorship of Darien \\
\hline & & $\begin{array}{l}\text { (v) National Council of Sustainable Development's (CONADES) regional } \\
\text { technicians (2) }\end{array}$ \\
\hline & & (vi) Darien Development Program's director (PRODAR) \\
\hline Local colonist organizations $^{*}$ & 6 & (i) Confidential (6) \\
\hline \multirow{5}{*}{ Regional organizations* } & \multirow{5}{*}{6} & (i) Catholic Church \\
\hline & & (ii) National Association for Ranchers (ANAGAN) \\
\hline & & $\begin{array}{l}\text { (iii) Centre for Investigation in Sustainable Systems of Agricultural Production } \\
\text { (CIPAV Foundation) }\end{array}$ \\
\hline & & (iv) Conservation Research Education Action (CREA) \\
\hline & & (v) Confidential (2) \\
\hline \multirow{4}{*}{ National organizations* } & \multirow{4}{*}{4} & (i) Smithsonian Tropical Research Institute (STRI) \\
\hline & & (ii) Tropical Agricultural Research and Higher Education Centre (CATIE) \\
\hline & & (iii) University of Panama \\
\hline & & (iv) Instituto Cooperativo Interamericano (ICI) \\
\hline \multirow{2}{*}{ International organizations ${ }^{*}$} & \multirow{2}{*}{2} & (i)UN Development Program (UNDP) \\
\hline & & (ii) UN-REDD \\
\hline Total & 29 & \\
\hline
\end{tabular}

*Nongovernmental, hereafter referred to as "organizations," in contrast to government.

first meeting, all available members of the group (two women and six men; October 2011-February 2012) responded to a semistructured interview to discuss perceptions of REDD+, the cooperation and spirit of solidarity that are present in the colonist communities, the capacity, advantages and barriers for organization, and the possibility for organizing and regrouping in the context of REDD+. The interview also included a section on the willingness, perceptions, and interests of each member in a possible REDD+ pilot initiative as a future project for the association. The data that were collected were supplemented with three semistructured interviews carried out with members of NGOs who had previously worked with the group. Finally, a focus group (ten participants) with the members was organized (February 2012) to discuss and verify the results of the interviews.

2.3. Data Analysis. All interviews and focus groups of phases two and three were recorded and transcribed. We supplemented verbatim transcriptions with field notes, which represent “ongoing 'stream-of-consciousness' commentary about what is happening in the research [24]." The data that were collected during interviews and from the focus group were analyzed independently using the "Framework" method [25] consisting of five steps allowing to systematically manage data and, ultimately, to describe, interpret, map, and explain the subject of interest. The method consists of (i) identifying the principal themes, (ii) labelling, (iii) sorting and (iv) summarizing the text, and (v) interpreting the results. Each theme was inserted into a matrix where rows represented individual respondents and the columns represented subthemes [26]. We applied the techniques that have been presented by Ryan and Bernard [27] to identify common themes. The text was coded (assisted by TAMS Analyzer version 4.13b9hs; http://sourceforge.net/projects/tamsys/files/) using "code and retrieve" methods, which consist of creating and structuring a scheme that regroups different categories and applying it to the whole data set to look for and retrieve labelled portions of the text [25]. In addition to "Framework," a comparative analysis was made of the different groups to verify similarities and differences in their perspectives. Presentation of the results was complemented with quotations that were gathered during group discussions and interviews.

\section{Results and Discussions}

3.1. Phase One: Stakeholders and Majors Issues of REDD+. When the hypothesis that territorial conflicts could potentially affect REDD+ implementation in Panama was presented, all participants from both workshops agreed that these situations could seriously undermine REDD+ initiatives in Panama. In occurrence, recent invasion of land in an IP community of Eastern Panama prevented a REDD+ pilot project from successfully attaining its objectives [28]. All respondents also mentioned that conflicts will continue 


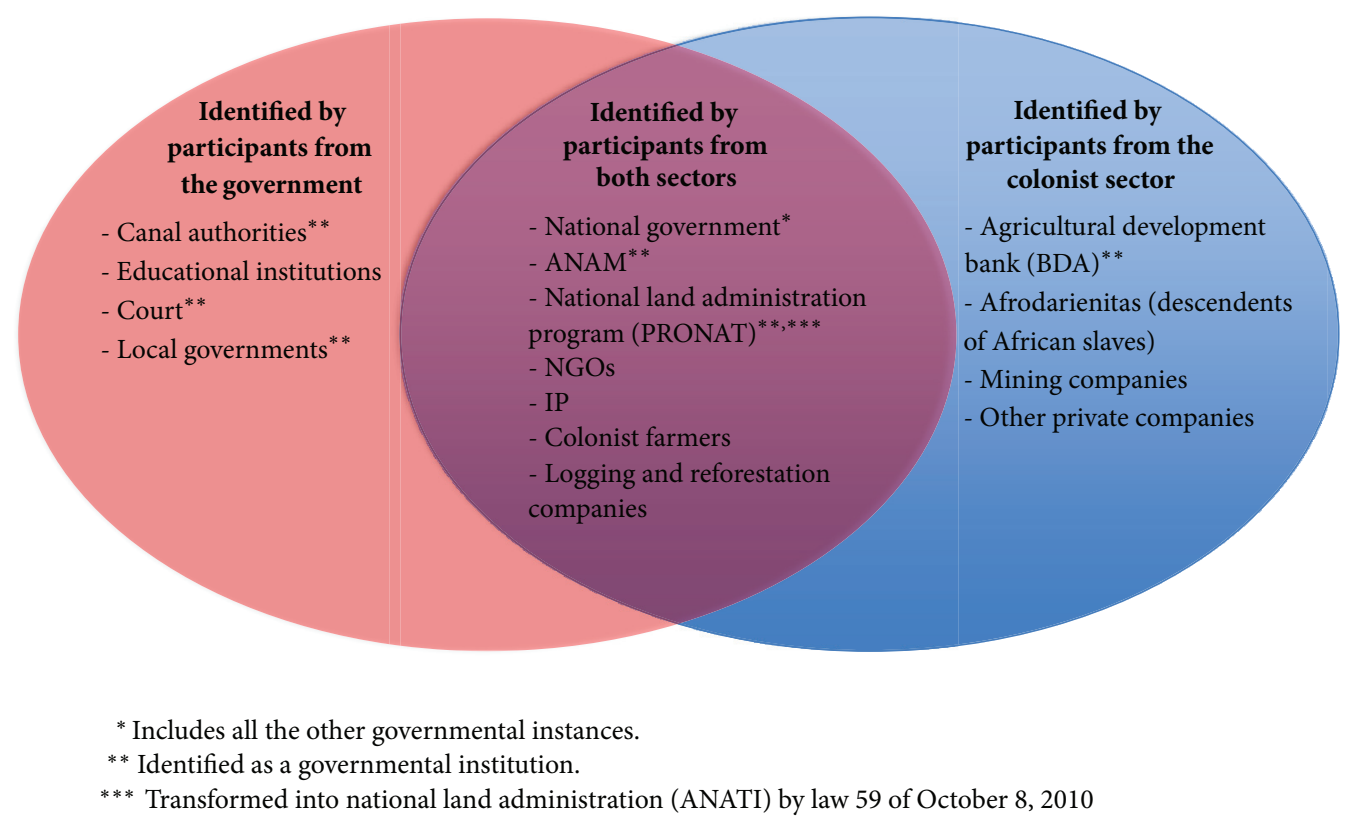

FIGURE 2: Different REDD+ stakeholders who were identified during phase one.

until the government assumes its responsibilities by clearly, firmly, and officially proclaiming boundaries on maps and in the field; "some colonists know they are illegally invading, whereas others think their actions are legal because some areas are not clearly and officially delimited" (colonist sector's workshop).

Participants from both workshops identified a total of 15 important actors for REDD+ implementation (Figure 2). In terms of issues, a majority of participants from both sectors criticized the lack of support and policies at the local level and the weakness of the national government in supporting conservation programs. Insecure land tenure was unanimously identified as increasing deforestation and generating conflicts among different actors, especially colonist farmers and IP. Correspondingly, clarification of land tenure is considered as critical in explaining participation and success of REDD+ or PES programs [29-31], while unresolved land claims in Panama are identified as an obstacle to the implementation of a successful REDD+ mechanism [4]. Also, most participants from both workshops agreed that the lack of environmental awareness, the absence of alternatives to deforestation, and the prominence of cattle ranching were problematic. Finally, a majority of participants from both workshops deplored the fact that the rights, interests, and obligations of the REDD+ potential actors are still unclear in the national readiness plan.

A great number of governmental participants said that the implementation of compelling policies to control deforestation, together with an increase in resources and financial allocations to governmental conservation facilities (e.g., local ANAM offices), would represent a considerable step towards halting deforestation. These same respondents were also critical of civil society. Notably, they qualified the influence of some unions and NGOs as negative, since they "may be in conflict with what other parties want or need" (government sector's workshop). In contrast, most colonist organizations emphasized their lack of trust towards the government (especially ANAM in the context of REDD+), which they perceive as extremely corrupt. A majority of respondents from the colonist sector also think that nongovernmental entities should be given responsibilities in developing REDD+ strategies and later in administering and distributing the sizeable quantity of funds that would flow into the country. They have denounced the lack of a participatory process and support for organized groups and the absence of demonstration initiatives in the context of REDD+ readiness actions. Finally, some respondents from the colonist sector were concerned about the lack of clarity and uncertainties of the details that are currently provided regarding many aspects of REDD+ (i.e., payment procedures, cost benefit analysis, other procedures, and how to qualify for REDD+ projects).

\subsection{Phase Two: Perception of the Different Groups of Respon-} dents. This research phase focused on the identification of the concordant and divergent perceptions of representatives of local/regional government, together with local colonist, regional, national, and international organizations regarding the principal barriers to (Table 2) and elements of success of REDD+ (Table 3) at the agriculture frontier.

3.2.1. Concordant Perceptions on Barriers to REDD+ Implementation. All interviewees consider colonists' land use activities (Table 2), and more specifically cattle ranching, as one of the main barriers to conservation initiatives. The literature likewise commonly considers cattle ranching as the main driver of deforestation throughout Latin America [3234]. Accordingly, more than half of the respondents from all groups called attention to the deficiency or lack of technical knowledge in explaining why land use activities often lead to unsustainable and harmful practices. "Colonists do not know how to work the land. They often aim for quantity instead 
TABLE 2: Main barriers to REDD+ implementation in colonist areas that were identified by the different groups of actors during phase two. Each barrier was classified as being mentioned by $(+++)$ all respondents of the group; $(++)>50 \%$ of the group; $(+) \leq 50 \%$ of the group; or $(-)$ no respondent of the group. The group "international organization" can only be represented by $(+++),(+)$, or $(-)$ because it consisted of only two respondents.

\begin{tabular}{|c|c|c|c|c|c|}
\hline \multirow{2}{*}{$\begin{array}{l}\text { Barriers (classified in order of importance, } \\
\text { i.e., by adding the “+") }\end{array}$} & \multirow{2}{*}{$\begin{array}{c}\text { Government } \\
\text { Local/regional (11) }\end{array}$} & \multicolumn{4}{|c|}{ Organizations } \\
\hline & & Local colonist (6) & Regional (6) & National (4) & International (2) \\
\hline (1) Land use activities & +++ & +++ & +++ & +++ & +++ \\
\hline (2) Culture & +++ & ++ & +++ & +++ & +++ \\
\hline (3) Territorial conflicts & +++ & ++ & ++ & ++ & +++ \\
\hline (4) Lack of trust towards the government & ++ & +++ & ++ & ++ & + \\
\hline (5) Hollow frontier dynamic & + & + & + & ++ & +++ \\
\hline (6) Poverty and necessities & + & +++ & ++ & + & + \\
\hline (7) National policy & ++ & + & ++ & ++ & + \\
\hline (8) Weak local government & ++ & - & + & + & + \\
\hline (9) Land market & + & + & ++ & - & - \\
\hline
\end{tabular}

TABLE 3: Elements of success for REDD+ implementation in colonist areas that were identified by the different groups of actors during phase two. Each element of success was classified as being mentioned by $(+++)$ all respondents of the group; $(++)>50 \%$ of the group; $(+) \leq 50 \%$ of the group; or $(-)$ no respondent of the group. The group "international organization" can only be represented by $(+++),(+)$, or $(-)$ because it consisted of only two respondents.

\begin{tabular}{|c|c|c|c|c|c|}
\hline \multirow{2}{*}{$\begin{array}{l}\text { Elements of success (classified in order of importance, } \\
\text { i.e., by adding the "+") }\end{array}$} & \multirow{2}{*}{$\begin{array}{c}\text { Government } \\
\text { Local/regional (11) }\end{array}$} & \multicolumn{4}{|c|}{ Organizations } \\
\hline & & Local colonist (6) & Regional (6) & National (4) & International (2) \\
\hline (1) Clear benefits & +++ & +++ & +++ & +++ & +++ \\
\hline (2) Tech. alternatives and knowledge & +++ & +++ & +++ & +++ & + \\
\hline (3) Efficient project administration & ++ & +++ & +++ & ++ & +++ \\
\hline (4) Environmental awareness & +++ & + & ++ & +++ & +++ \\
\hline (5) Participatory process & - & +++ & ++ & +++ & + \\
\hline (6) Demonstration and pilot activities & + & + & + & +++ & +++ \\
\hline (7) Binding environmental policies & +++ & - & + & ++ & - \\
\hline
\end{tabular}

of quality" (local/regional government). For example, cattle ranching is so extensively practiced that ranchers maintain very low stocking rates $\left(<1 \mathrm{cowha}^{-1}\right)$ [33-36]. Over the course of a year, the area needed to keep one cow can even be increased to two or three hectares due to a decline in pasture carrying capacity [10].

Colonist culture (Table 2) was also commonly presented as a barrier to REDD+. Interviewees, with a single exception, insisted on the "antitree" customs of colonists. This culture is associated with prestige status and an appreciation for extensive cattle ranching or "culture of the pasture" [10, 34], which often leads to massive deforestation. "Most colonists are proud to say 'I am a cattle rancher.' For them, a 'pretty' and productive farm consists of countless hectares of pasture with very few or no trees at all" (international organization). Under these circumstances, five respondents from regional, national, or international organizations even believe that REDD+ would likely not appeal to colonists:

Their fundamental demonstration of success resides in large parcels of pasture to practice cattle ranching, and any forest conservation project represents a contradiction with this ultimate objective (national organization).

Lastly, a total of 7 respondents from national and international organizations as well as from the government identified the idea of "conquest of Darien," as discussed in the literature $[10,11]$, as an intrinsic component of the Panamanian culture; "deforestation is part of a complex historical mixture of national mythology and centrality of Darien's conquest and its role as a frontier" (national organization).

However, most respondents (85\%) insisted that Eastern Panama was depleted of its last national lands available for colonization; "forest colonization does not happen anymore; all national land is now owned by someone" (regional organization). Given the impossibility of migrating further into the forest, as many as 22 of 28 respondents revealed that colonists are illegally migrating into the last "available" forests, which are those located in national parks and in indigenous territories. "Because of land scarcity, colonists invade or log timber inside national parks or IP areas. Many confrontations occurred between colonist farmers and IP with deaths and injuries as a result" (regional organization). 


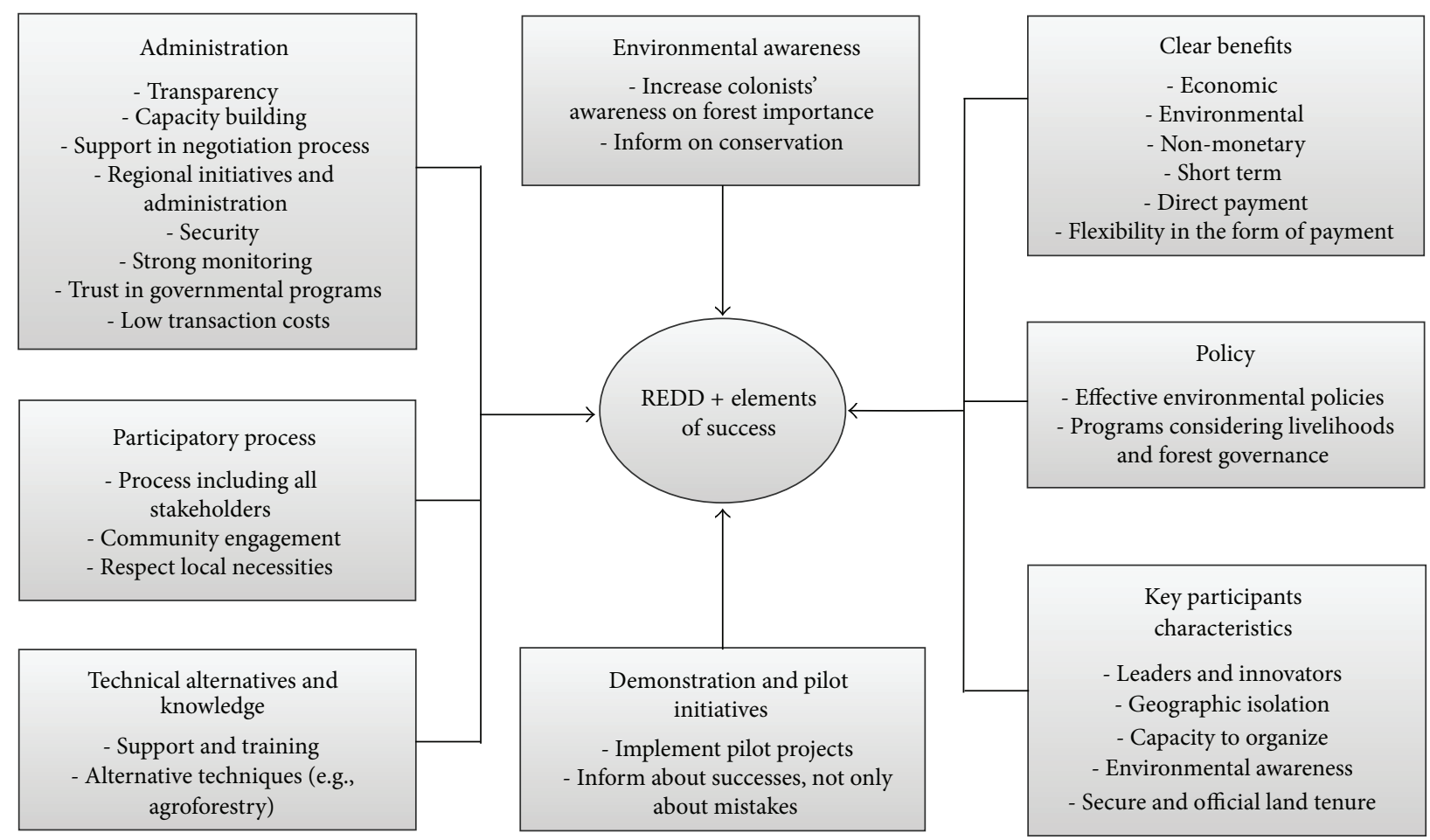

FIGURE 3: Synthesis of the elements of success for REDD+ implementation in colonist areas that were identified by the different groups of actors during phase two.

These territorial conflicts (Table 2) were identified as important barriers to REDD+ implementation, as was the case in the workshops held by CERCA.

Finally, as many as 20 respondents, from all groups, believed that colonists neither trust nor are willing to participate in programs that are administered by the government (Table 2). This suspicious attitude that have been ascribed to colonists is exacerbated by a feeling that REDD+ could undermine their rights over land or lead to expropriation [37] and by previous negative experiences; "colonists do not trust the government and its capacity to manage, mainly because of past unproductive or harmful experiences" (national organization). This general mistrust of the government indicates the urgent need for fair and transparent compensation programs, supported by honest managers and intermediaries who could overcome distrust and permit confidence building among the different actors [23, 38, 39]. Members of the local/regional government do not question the leading role of government and contend that transparent and extensive work with colonists would be sufficient to win back their trust. In a different way, some respondents of regional, national, and international organizations have instead deemed that the establishment of comanagement structures involving unbiased independent organizations and the inclusion of colonist groups and leaders in dialogues and decision-making processes could create a trustful environment. More drastically, local colonist organizations strongly believe that the government should not be the entity in charge of REDD+ (especially for money management), without proposing clear alternatives.
3.2.2. Concordant Perceptions on Elements of Success for $R E D D+$. The elements of success for REDD+ implementation are synthesized in Figure 3, which includes all elements that were identified by at least one group of respondents, whereas Table 3 illustrates the divergences between the groups. Support for technical alternatives and knowledge (Table 3) was mentioned as a priority by four of the five groups of respondents. Only one interviewee, who was a member of an international aid organization, argued that REDD+ is principally a PES that should not include technical components, at least at its starting point. The remaining respondents believed that REDD+ success depended on improvements in land use activities and farm management; "technical support would be helpful in order to reduce needed area and identify more sustainable ways to work and organize the farm (local colonist organization). The most important progress that was mentioned concerned intensification" (i.e., higher cow ha ${ }^{-1}$ stocking rates) and the endorsement of alternative techniques for cattle ranching:

Cattle ranching does not necessarily lead to destruction and deforestation. The environmental component cannot be forgotten, and more intensive techniques such as silvopastoral activities could reduce deforestation (local/regional government).

Notwithstanding, plainly intensifying agriculture, and thus profitability, could encourage land expansion and deforestation; "trade-offs and win-lose between forest conservation and technological progress in agriculture in areas near 
TABLE 4: Potential REDD+ benefits expected to be provided to colonists that were identified by the different groups of actors during phase two. Each benefit was classified as being mentioned by $(+++)$ all respondents of the group; $(++)>50 \%$ of the group; $(+) \leq 50 \%$ of the group; or $(-)$ no respondent of the group. The group "international organization" can only be represented by $(+++),(+)$, or $(-)$ because it consisted of only two respondents.

\begin{tabular}{|c|c|c|c|c|c|}
\hline \multirow{2}{*}{$\begin{array}{l}\text { Type of benefits (classified in order of importance, } \\
\text { i.e., by adding the "+") }\end{array}$} & \multirow{2}{*}{$\begin{array}{c}\text { Government } \\
\text { Local/regional (11) }\end{array}$} & \multicolumn{4}{|c|}{ Organizations } \\
\hline & & Local colonics (6) & Regional (6) & National (4) & International (2) \\
\hline (1) Economic & +++ & +++ & +++ & +++ & +++ \\
\hline (2) Environmental/ecosystem services & ++ & - & ++ & +++ & +++ \\
\hline (3) Direct payment & + & +++ & + & + & + \\
\hline (4) Short-term & + & +++ & + & + & - \\
\hline (5) Nonmonetary (i.e., extra project) & ++ & - & + & ++ & + \\
\hline
\end{tabular}

forests appear to be the rule rather than the exception [40]." Consequently, results from our study show that "zones with forestry purposes" (international organization), such as Eastern Panama, should prioritize alternatives such as agroforestry or silvopastoral systems (mentioned by more than half of the respondents) that integrate trees into farm management [41-43], helping to diversify production and increase yields [44]. However, respondents insisted that this support needs to be complemented with suitable policies and programs that are adapted to local customs (e.g., cattle ranching).

Another important aspect that was discussed, with no evident dissent amongst groups, concerned REDD+ project administration (Table 3). Two-thirds of the respondents advocated transparent and clear presentation of the objectives, prerequisites, and details of the project; "for REDD+ to be successful, the organization in charge needs to clearly present the project, its rules, norms, conditions, and objectives" (regional organization). Transparency can be increased by making information on REDD+ available at all levels (national, regional, and local), both before and during the completion of the projects [23]. Strong capacity building and support for local NGOs and governments on REDD+ and its negotiation process could increase the understanding and participation of local colonist communities [7]. At least one respondent per group insisted on the importance of having regional initiatives and administration:

\section{If the state manages the entire project, the admin- istration will dangerously become very centralized and, thus, inefficient. The initiatives have to be regional with a lot of autonomy and resources given to local administrations (national organi- zation).}

The fear that REDD+ could concentrate power in a few hands, as expressed by interviewees of local colonist, regional, and national organizations, has been referred to as the “"nationalization' of carbon rights" by Angelsen et al. [45], who have suggested that it could lessen participation and benefits provided to local communities. Different points of view were encountered with respect to the approaches favoured regarding the geographical scale of REDD+ (for a description, see $[16,45])$. On one hand, local colonist and regional organizations have preferred a subnational approach, which provides greater opportunities for community participation, offers enhanced short-term results, and responds better to specific local contexts and necessities. On the other hand, local/regional governments, together with national and international organizations, have supported a national approach, including a flexible countrywide strategy that permits regional and local initiatives in the context of a national vision and which allows long-term accomplishments, strong control over leakage, and simultaneous conservation of larger areas of forest.

Furthermore, all respondents judged that REDD+ initiatives would be successful only if they offered clear benefits (Table 3). "If you arrive there and give them benefits, this serves the colonist. But if you prevent them from deforesting without giving anything, they will say 'how do I survive?"” (regional organization). Nevertheless, dissimilarities were found in the expected types of clear benefits for REDD+ that could be accepted and efficient (Table 4). Economic benefits (Table 4) are paramount in all groups; "until all these models of PES, carbon sequestration, and ecosystem services production, such as water or biodiversity, do not materialize in terms of monetary disbursement, there are not enough incentives to be seen by colonists" (international organization). In brief, the compensation that is provided by reducing deforestation will have to be higher than the current income of colonist farmers, and their decisions to participate in REDD+ will ultimately depend on the weight of the payment [46]. Notwithstanding, such an opportunity cost approach, which is proposed by many researchers [47-49], holds numerous problems in practice, including its inadequacy in some circumstances (e.g., lack of clear land tenure, illegal activities, strong political incentives for deforestation), the difficulty in evaluating actual opportunity costs to local communities, and the frequent disregard of local communities' opinions (i.e., perceived opportunity cost) [50].

Local colonist organizations were the greatest advocates of direct payment (Table 4), which involves no intermediary, mainly because they fear that the State will retain financial benefits, an apprehension that is shared by civil society worldwide [51] and which is prevalent in Panama where very few details are given regarding transparency and mechanisms of financial distribution and benefit sharing [52]. Conversely, some respondents (48\%) of the four other groups believe that payment for reducing deforestation should be complemented 
with nonmonetary benefits (Table 4), more likely to be equitable, sustainable, and perceptible by participants than direct payments [53]. This divergence in opinions concurs with the fact that preference for compensation types can strongly vary between areas, land tenure situations, communities, families, and even individuals [54], and that flexibility is recommended [23]. Local colonist organizations, most probably because of their knowledge of colonist realities, have also considered that REDD+ needs to generate short-term unambiguous benefits (Table 4); "colonists have daily necessities, and benefits need to be quickly perceived if REDD+ is to be a viable option for them" (local colonist organization). This confirms the claims that REDD+ effectively needs to consider urgent necessities of local communities [50], and that "the scheduling of benefit delivery fits with the time horizons of the poor [7]."

As stated at the outset, REDD+ possesses a strong potential to generate ecological cobenefits $[55,56]$, and more than half of the respondents from all groups, except local colonist organizations, have emphasized the importance for REDD+ in raising environmental awareness (Table 3) and generating environmental benefits (Table 4):

\section{Colonist farmers have to understand that their own practices are the sources of multiple environ- mental problems, and more importantly, that they can do something about it. I believe they would perceive more benefits from forest conservation projects if they made the link with water qual- ity, abundance, and conservation (international organization).}

These respondents consider that REDD+ projects focusing solely on income-generating activities and neglecting benefits that are provided by forest conservation and its resulting ecosystem services could create temporary incentives for colonists to conserve, lasting only until payments stop or more profitable alternatives are encountered. Encouragingly, PES in northern Costa Rica have been shown to be successful in raising farmers' awareness about forest and ecosystem services [57]. In contrast, even though respondents from local colonist organizations have also acknowledged the importance of forest conservation for ecosystem services, they mostly believe that REDD+ will be perceived as an income generator and that resources should thus be spent on financial compensation.

3.2.3. Noteworthy Divergent Perceptions. A majority of respondents from the local/regional government (70\%) strongly consider that the weak capacities of local government (Table 2) could represent an impediment to measuring, reporting, and verifying possible emissions reductions or proceed payments $[16,23,58,59]$ in a future REDD+ strategy. Amongst other factors, the lack of employees and resources, poor working conditions (e.g., low salaries, often leading to corruption), and the lack of power to implement laws were highlighted as difficulties. Conversely, local colonist organizations all insisted that a stronger local government would probably lead to repressive behaviours undermining the life of colonist communities. Here an important question becomes whether or not efficient investments at the local level (e.g., capacity building, infrastructure project) will be the consequence of REDD+ programme investing money and increasing power of local governments. Investments in human resources and infrastructure will be essential to ensure that potential resources invested into local government are efficiently used [23].

Most respondents from the government (70\%) ignored poverty when identifying barriers to REDD+ (Table 2); one respondent even mentioned that colonist farmers often use this argument to justify deforestation and their practices. The fact that members of the government see weak governmental capacities as greater barriers than poverty and inequalities lent credence to concerns that repressive approaches by law enforcement could be encouraged and preferred by governments over other options, including poverty alleviation $[51,60]$. In contrast, the poverty, numerous needs, and lack of alternatives that are typically encountered on agriculture frontier [32, 61, 62] were identified by all local colonist and many regional organizations as largely contributing to deforestation, which was classified as "a logical decision since it is the sole alternative we have" (local colonist organization). The more intimate acquaintance of these two groups with the "nature of the aspirations of the poor to get themselves and particularly their children out of poverty, and their perceptions of what is needed to do so" [50] might explain why they singled out poverty as a barrier. National and international organizations have mainly considered poverty as an indirect issue; "poverty, even if not a cause of deforestation, often accompanies the process" (international organization).

A total of 59\% of respondents from all groups mentioned that colonists often apply observational learning, implying that they observe, learn, and reproduce the successful actions of others around them; "for colonist farmers, 'seeing is believing;' few will accept change without firstly witnessing success" (national organization). A study on agroforesty in Panama also emphasized farmers' reluctance to participate and invest in a project with unproven benefits [63]. Throughout the world, demonstration activities are common approaches to gaining knowledge on how to implement and develop REDD+ $[16,51,64,65]$. That being said, only respondents from national and international organizations unanimously prioritized demonstration and pilot activities (Table 3) as an element of success for REDD+, mainly because it would permit neighbouring colonists to evaluate both risks and benefits. Nonetheless, two respondents of the national organizations also advocated caution when developing proxies, since a single failure to accomplish the colonists' expected outcomes could lead to widespread disinterest and distrust. Thus, we argue that pilot initiatives should not be considered as a way to "learn from mistakes" and get a sense of a colonist's interest in REDD+, but rather be well organized to ensure FPIC and community-wide consultation and participation throughout the whole process so that participants are pleased with the project and its results.

Furthermore, perceptions of respondents on barriers to REDD+ implementation varied on three other aspects that have already been largely documented in the literature (Table 2): potential consequences of hollow frontier dynamics [10, 
$11,32,62,66,67]$, national policies (i.e., agrarian codes that permit land possession through land clearing $[10,13,32,68]$ and loan systems that encourage cattle ranching $[32,33,69]$ ), and land markets (i.e., deforested areas possess a higher financial value when sold $[32,69,70])$. Also, perceptions on elements of success diverged in terms of the weight that should be given to participatory processes and binding environmental policies (Table 3).

3.3. Phase Three: Detailed Study of Communal Organization. The last part of this paper explores the social structure of colonist areas and contrasts perceptions on elements of success of REDD+ with those of OCA members in a context of potential collaboration between landowners. We mainly sought to explore the potential communal organization in the context of REDD+ and identify why OCA has been successful in organizing itself.

3.3.1. Context: Social Structure in Colonist Areas. All members of OCA, together with half of the interviewees from phase two, perceived the social structure in colonist areas as diffuse and lacking of a sense of community. Seven respondents from phase two, mostly from regional and national organizations, compared colonists with IP to illustrate why their weak social structure explains both their insubstantial role within civil society and their underrepresentation in development programs:

IP fight for their culture, work together, are very organized with their traditional authorities, show a lot of solidarity, and always work together, which permits them to reach interest of civil society and international aid institutions. In contrast, even though colonists have political representatives controlling regions, they do not have collective structure or organization within communities (regional organization).

Considering REDD+, respondents from OCA are worried because their communities are dangerously uninformed and unprepared for REDD+ and lack community structure. This could indeed become a challenge, for example, when organizing meetings, identifying and communicating with key stakeholders, and obtaining and distributing future REDD+ payments. A member exemplified their lack of preparation by comparing colonists with IP:

They are preparing for REDD+ since 2005 and are way more advanced than colonists. By looking at them, I could realize the importance of organization to access and improve capacity building, benefits, negotiations, and dialogue. We have to unify like the IP and fight for our rights.

Respondents of OCA see the consequences of this lack of organization in a manner similar to the view expressed by Rosa et al. [71]:

Without strong internal organization and external linkages, poor communities cannot influence the rules of PES schemes, nor can they effectively conduct struggles to expand, defend, and secure their rights to the resource base.

With this in mind, we argue that the capacity of IP to organize provides them with an ability greater than that of individual farmers to increase their visibility by communicating and cooperating with the broader civil society. This could partially explain why IP monopolize most of the discussion on REDD+ in Panama, whereas colonists have not been consulted to date. Despite the mention of indigenous peoples and local communities' attempts to be far reaching, Thompson et al. [72] argue that many nonindigenous local communities risk being left out of REDD+ because potential political exclusion can be incurred by applying the label "indigenous." In fact, the "attention to indigenous peoples can marginalize the nonindigenous [73]," especially since gaining access to the negotiations at different levels necessitates the expenditure of many resources (e.g., funding, passports, patronage) that can often only be offered by a limited number of national and international aid institutions. For instance, heightened interest in working with the Maasai and Parakuyo peoples of Tanzania led to the exclusion of nonindigenous groups from the same region [74].

According to all respondents from phase two as well as OCA, culture explains why colonists "think individualistically and prioritize their personal interests over community and collective work" (national organization). Three reasons were given by the interviewees to explain this difference. First, most of the local colonist organizations (83\%) and all OCA members attributed this phenomenon to education and tradition; "working as a group is very hard for us since our education at home was very individualistic" (local colonist organization). Heckadon Moreno provides historical justification for this feeling, which continues to be felt within Panamanian rural families, in that large landowners employed legislation at the beginning of the 20th century to destroy peasant communal institutional and tenure initiatives [70].

Second, 17 interviewees, who were mostly from government (4), OCA (6), and regional (2) and national (3) organizations, suggested that individualism is explained by the private property regime characterizing agricultural frontiers. A respondent of the local/regional government described this trend as the "fence phenomenon," "the fences used by colonists to delimit their farms are present in their mentality, in their culture. Their family teaches them to possess property, which leads them to be egoistic." Similarly, a member of OCA mentioned that:

The majority of the collective initiatives fail because colonists mostly want to work individually on their property and are self-centred. Even in our group, there is a lot of individualism, and members prefer personal over collective benefits (respondent 1, OCA).

This notion of presumptive ownership is at the base of all agriculture frontiers; any colonist "who works the land, owns it [32]." As Wali explains about eastern Panama, "poor 
colonists did not stake their claim to land through concerted, collective political action. Even economically, they tended to act as individuals [13].”

Third, five respondents from regional, national, and international organizations argued that individualism is a consequence of the process of agriculture frontier colonization:

Colonists at the agricultural frontier are thinking
about how they can survive, develop and produce
instead of their community. Each colonist will
proudly explain his or her story on how he or she
developed without the help of the government, or
anybody else (national organization).

Since very few colonists successfully achieve first colonization $[10,62]$, or more precisely "nine colonists out of ten fail" (national organization), the struggle to colonize and the hard conditions on the frontier push colonists to prioritize family and "egoism" over the community. A study in Brazil illustrates this lack of kinship on the frontier; "due to the precipitous rate of onward migration, colonists had difficulty in building a community and working toward communal ends [35]."

3.3.2. Implications for $R E D D+$. In the light of these results, it appears that REDD+ initiatives with colonist farmers could hardly be implemented as equally as is the case in IP territories where land is owned collectively. This suggests that community-based forestry, which is seen as a sound option for REDD+ initiatives [75] and represents the main model for PES programs in Mexico [76], might not be appropriate in colonist areas of Panama. In fact, all members of OCA, mirroring respondents from local colonist organizations, consider that REDD+ will only be possible if benefits are rewarded with a direct monetary payment:

Organization would be possible only if farmers who have more forest receive more benefits. A committee would have to evaluate every farm to see how many hectares are available, and then the money would be distributed equivalently to how much each participant is protecting (respondent 6, OCA).

Nevertheless, a problem with this approach is that REDD+, like previously implemented PES programs, could seek economies of scale and be biased towards large landowners (e.g., the state, rich entrepreneurs, concessions) [77] to reduce the transaction costs associated with numerous operations [7, 39, 53, 78, 79]. In effect, some PES initiatives have even established a minimum contract size (e.g., 50 ha for PROFAFOR in Ecuador [80]; 200 ha in Mexico [81]).

A majority of members of OCA proposed an innovative approach that resides in a system of collective contracting with posterior money delivery to landowners, a strategy already used in the Costa-Rican PES [71]. As Wunder mentions, "working with three ES providers will almost always be easier than working with three hundred [54]."

During the focus group, respondents from OCA mentioned that, if unified, they could gain stronger negotiation capacity and improve consultation, while countering possible corruption and ineffective management:

Even though the government has around eight million USD to prepare REDD+, they did not invest anything in consultation with colonist communities. If we can organize ourselves and account for more forest, we would be considered as more important, make sure our rights are respected, possess a stronger negotiation power, and force the government to become transparent (workshop 2, OCA).

Members of OCA illustrated this stronger negotiation power with a hypothetical scenario where they regrouped to participate in a REDD+ scheme. In short, the average forested area that is encountered on their separate farms is about $42.5 \mathrm{ha}$, of which 28 ha are in primary forest. This might imply that many of these farmers would not be considered for PES or REDD+ initiatives if the minimum contract size accepted for such initiatives in Panama is defined using the criteria previously adopted in Mexico or Ecuador. However, when the farms are pooled ( 7 farms, total of $928 \mathrm{ha}$ ), a considerable 297.5 ha of forest ( $66 \%$ in primary forest) would become available for conservation. In this context, an important issue that was brought up by the respondents is that noncompliance of one participant could lead to termination of the contract. A solution that had been applied in Costa Rica was to issue individual contracts within collective agreements [79].

Like local colonist organizations, all the members of OCA suggested that the government should not fully administer REDD+. In their own way, however, they also suggested that colonist organizations, such as cooperatives, village committees, or credit unions [7], could be used (or created) to deliver the payments. This would offer security and give trust to the colonists that "do not trust the government in managing the money and proceeding to the payments" (respondent 6, OCA). Local organizations were indeed identified as key intermediaries in local-scale PES projects [39]. Nevertheless, elite captures and inequalities could occur due to weak governance [54] or to unequal structures of power, which could lead to groups being controlled by small proportion of the local population [53].

In contrast to the respondents from local colonist organizations who did not consider pilot projects as essential, all OCA respondents believed that they represent the best way to introduce REDD+ into their area. They think that successful demonstrations would raise awareness in the communities and show the benefits of REDD+:

If 5 or 6 colonists protect forest, the communities
will not only realize the economic benefits of
participating in REDD+, but will also see the
advantages of maintaining more forest, such as a
better climate, more water, and better soil quality
(respondent 1, OCA).

The fact that pilot projects have always remained at the roots of OCA's initiatives (two projects in the last five years) might explain the attraction of its members to this option. 
TABLE 5: Key group characteristics needed for success that were mentioned by the respondents of OCA during phase three.

\begin{tabular}{|c|c|c|}
\hline Key characteristics & Details & Quotes representing the majority of the comments \\
\hline Leadership & (i) Leaders and motivators & $\begin{array}{l}\text { (i) "Leadership is a very important part of an } \\
\text { association, since there is always people that need to } \\
\text { motivate one another, organize projects, and lead the } \\
\text { meetings" (respondent 2). }\end{array}$ \\
\hline External support & $\begin{array}{l}\text { (i) Multiple sources } \\
\text { (government, NGOs, } \\
\text { international) } \\
\text { (ii) Flexible, accessible, and } \\
\text { long-term accompaniment } \\
\text { (iii) Capacity building and } \\
\text { support: } \\
\text { (a) Social capital } \\
\text { (b) Technical } \\
\text { (c) Administration and } \\
\text { management } \\
\text { (d) Legal } \\
\text { (e) Financial }\end{array}$ & $\begin{array}{l}\text { (i) "It is very important to learn how to work in groups" } \\
\text { (respondent 7). } \\
\text { (ii) "We received a lot of support from regional NGOs, } \\
\text { governmental programs, and funds from international } \\
\text { organizations. Without this support, we would never } \\
\text { have succeeded in forming a group and realizing } \\
\text { projects" (respondent } 1 \text { ). } \\
\text { (iii) "We only had to call them for any technical or legal } \\
\text { questions and they were coming directly" (respondent } \\
\text { 2). }\end{array}$ \\
\hline
\end{tabular}

(i) Constant motivation of members $\begin{array}{ll}\text { Motivation } & \text { (ii) Multiple project } \\ \text { opportunities }\end{array}$

(iii) Dynamism

(iv) Generate results

$\begin{array}{ll}\text { Vision } & \begin{array}{l}\text { (i) Main objectives and vision } \\ \text { for the future shared by the } \\ \text { whole group }\end{array}\end{array}$

(i) A system of written rules

Rules that are democratically elaborated and approved

(i) "You always have to give a group resources and projects, with the ultimate goal to produce and motivate members" (respondent 5).

(i) Recognition as a legal entity

Administration capacity

(ii) Money management

(iii) Reporting

(i) "Many people would like to join the group, but it is important that they share our vision. For example, we aim at protecting the environment, and members cannot deforest or use chemicals" (respondent 4).

(i) "Written and internal rules are essential in a group. For example, if someone does not assist meetings, he can pay a fine or simply be expelled from the group" (respondent 1).

(i) Individually distributed

(i) "It is important to strongly manage the group and the money. At the beginning, we did not know how to report or ask for funding" (respondent 2).

Provision of benefits

(ii) Clear and shortterm

(i) "We have the advantage of offering rapid benefits

(i) Regular meetings

(ii) Clarity and transparency

Communication

for all members on projects,

finance, challenges, and

opportunities directly on the farms of the members" (respondent 6).

(i) "There is always a need to meet in order to share information and go forward with new projects. Communication between members makes an organization successful" (respondent 7).

Furthermore, respondents, by mentioning that "REDD+ would be a perfect project for the continuity of our association" (respondent 5, OCA), admitted their self-interest in supporting the idea of a REDD+ pilot project (i.e., for their group to be selected). The only groups of phase 2 that strongly supported REDD+ pilot initiatives were the national and international organizations. A crucial question, which needs further research, thus becomes as follows: how will pilot projects be implemented, especially at the local level, without unanimous acceptance and support from all stakeholders of the affected sectors?

3.3.3. Elements of Success for Communal Organization. All OCA respondents insisted that working collectively towards conservation goals represents a challenge in colonist areas. Equally as in another study [78], 4 OCA members suggested that early REDD+ initiatives would take advantage of collaborating with already well-established groups that possess strong social capital, which includes strong networks, beliefs, values, trust, and common rules as well as sanctions, elements considered essential for collective action in regard to the environment [82]. OCA members identified essential group characteristics that permitted them to achieve collective efforts and that should be sought for in the context of REDD+ (Table 5). Specifically, the support received from external organizations was identified as the most important factor of success by all members. Support can indeed help to build social capital, while providing technical and organizational 
capacity [83-85], and gain legal recognition [78]. The presence of clear incentives is another factor that facilitates efficient group formation [39]. In addition, all members of OCA judged that the strong environmental awareness of each member helped the group in accomplishing projects and staying unified; "what pushed me to join OCA is the common conservationist vision that keeps the group unified. The impact of conserving forest with neighbours is more important than alone" (respondent 6, OCA). This most compelling evidence is extremely dissimilar to the perceptions of representatives of local colonist organizations who did not place any emphasis on the importance of environmental awareness and ecological benefits. We attribute this difference to the fact that all respondents from OCA mentioned that their members possess a stronger interest in conservation than other colonist farmers living in the area; "all the members of the group have the same vision to protect natural resources and forest" (respondent 5, OCA).

\section{Conclusion}

The preparation for REDD+ sets the stage for conflicting interests [51]. This paper has clearly shown that perceptions regarding REDD+ vary, depending on the context of the observers' own experiences and origins (e.g., sector, geographical scale). The perceptions of each observer are strongly influenced by his or her "cultural lens," which is defined as the "common knowledge, general cognitive frameworks, and values that are (more or less) shared by the members of a social group and that help them make sense of their world [86]." Cultural lenses are acquired through education, social relationships, and life experiences. For example, a logging company might see the forest as a profit generator, while forest-dependent farmers view it as a source of food, fuel, and livelihoods. REDD+ will demand interactions between stakeholders with divergent worldviews and beliefs. Failure to do so could generate conflicts and disagreements. The question thus becomes as follows: how will a REDD+ strategy "frame" all the issues, referring to "the manner in which parts are put together in a whole?" [86] The range of perceptions and the presence of conflicting interests among actors could complicate coordination and hold back conception and implementation of REDD+ projects [16], while resource capture by some sectors or institutions at higher levels and with strongest negotiation powers [23] might fuel inequalities, a concern clearly articulated by colonist organizations. Acknowledging perception heterogeneity, both in terms of promises and limitations, could permit the creation of a comprehensive long-term REDD+ strategy insuring the viability of such initiatives at the agriculture frontier.

\section{Acknowledgments}

This paper was financially supported by the David and Lucille Packard Foundation, while GPS was supported by Natural Sciences and Engineering Research Council of Canada (NSERC) and Fonds de recherche du Québec-Nature et
Technologie (FQRNT). The authors appreciate the invaluable assistance provided by CERCA. Special thanks are due to Dr. W. F. J. Parsons and Dr. D. Studnicki-Gizbert for their reviews and copy editing of earlier versions of this paper.

\section{References}

[1] UN-REDD, UN-REDD Programme: Panama, 2009, http:// www.un-redd.org/UNREDDProgramme/CountryActions/panama/tabid/1030/language/en-US/Default.aspx.

[2] FCPF (Forest Carbon Partnership Facility), Participants Committee Meeting (FCPF PC4): progress with due diligence activities in Panama, FCPF, Washington, DC, USA, 2009, http:// www.forestcarbonpartnership.org/fcp/sites/forestcarbonpartnership.org/files/Documents/PDF/Oct2009/11.g_Panama_ WB_Update.pdf.

[3] G. Vergara and C. Potvin, "Mapping Indigenous Territory in Panama: Role of Indigenous People in Forest Conservation," McGill University, Montréal, Canada, 2012.

[4] UN-REDD, UN Collaborative Program on REDD+ Joint Program Document: Panama, Government of Panama, UNEP, FAO, UNDP, Panama City, Panama, 2010, http://www.unredd.org/UNREDDProgramme/CountryActions/panama/ tabid/1030/language/en-US/Default.aspx.

[5] P. Anderson, Free, Prior, and in Formed Consent: Principles and Approaches for Policy and Project Development, The Center for People and Forests (RECOFTC), German Agency for International Cooperation (GIZ), Bangkok, Thailand, 2011.

[6] M. Colchester and M. F. Ferrari, Making FPIC-free, prior and informed consent-work: challenges and prospects for indigenous people, Forest Peoples Programme, FPIC Working Papers, Moreton-in-Marsh, England, UK, 2007.

[7] L. Peskett, D. Huberman, E. Bowen-Jones, G. Edwards, and J. Brown, Making REDD Work for the Poor, Poverty Environment Partnership, London, UK, 2008.

[8] J. Phelps, E. L. Webb, and A. Agrawal, "Does REDD + threaten to recentralize forest governance?" Science, vol. 328, no. 5976, pp. 312-313, 2010.

[9] CONADES (Consejo Nacional de Desarrollo Sostenible), Estrategia De Desarrollo Sostenible De La Provincia De Darién, CONADES, Panama City, Panama, 2008.

[10] S. Heckadon Moreno, De Selvas a Potreros: La Colonización Santeña en Panama, 1850-1980, Exedra Books, Panama City, Panama.

[11] W. L. Partridge, "The humid tropics cattle ranching complex: cases from Panama reviewed," Human Organization, vol. 43, no. 1, pp. 76-80, 1984.

[12] A. Hernandez, "Migracion de colonos en Darien," in Colonizacion Y Destruccion De Bosques En Panama, S. H. Moreno and A. McKay, Eds., pp. 105-118, Asociación Panameña de Antropología, Panama City, Panama, 1984.

[13] A. Wali, "The transformation of a frontier: state and regional relationships in Panama, 1972-1990," Human Organization, vol. 52, no. 2, pp. 115-129, 1993.

[14] A. J. García Aguilar, El modelo de la ganadería extensiva y la destrucción de los bosques en la República de Panamá: 1950-2000 [Ph.D. thesis], Universidad de Panama, Panama City, Panama, 2006.

[15] G. Peterson St-Laurent, C. Potvin, and N. Gélinas, "REDD+ and the agriculture frontier: understanding colonists' utilization of the land," Land Use Policy, vol. 31, pp. 516-525, 2012. 
[16] A. Angelsen, M. Brockhaus, M. Kanninen, E. Sills, W. D. Sunderlin, and S. Wertz-Kanounnikoff, Realising REDD+: National Strategy and Policy Options, Center for International Forestry Research (CIFOR), Bogor, Indonesia, 2009.

[17] A. Wali, Kilowatts and Crisis: Hydroelectric Power and Social Dislocation in Eastern Panama, Westview Press, Boulder, Colo, USA, 1989.

[18] ANAM (Autoridad Nacional del Ambiente), Informe Final de Resultados de la Cobertura Boscosa y Uso del Suelo de la Republica de Panama: 1992-2000, ANAM, Panama City, Panama, 2003.

[19] Contraloría General de la República de Panamá, Censos Nacionales de Población y Vivienda, 16 de Mayo de 2010, Lugares Poblados de la Republica, vol I, Dirección de Estadísticas y Censo, República de Panamá, 2011.

[20] A. Wali, "In eastern Panama, land is the key to survival," Cultural Survival Quarterly, vol. 13, no. 3, pp. 25-29, 1989.

[21] J. F. Gubrium and J. A. Holstein, Handbook of Interview Research: Context \& Method, Sage, Thousand Oaks, CA, USA, 2002.

[22] K. B. M. Noor, "Case study: a strategic research methodology," American Journal of Applied Sciences, vol. 5, no. 11, pp. 1602-1604, 2008.

[23] L. Peskett, Benefit Sharing in REDD+: Exploring Implications for Poor and Vulnerable People, World Bank and REDD-Net, Washington, DC, USA, 2011.

[24] K. M. Eisendhardt, "Building theory from case study research," Academy of Management Review, vol. 14, no. 4, pp. 532-550, 1989.

[25] J. Ritchie and J. Lewis, Qualitative Research Practice: A Guide for Social Science Students and Researchers, Sage, London, UK, 2003.

[26] J. Ritchie and L. Spencer, "Qualitative data analysis for applied policy research," in Analyzing Qualitative Data, A. Bryman and R. G. Burgess, Eds., Routledge, Abington, UK, 1994.

[27] G. W. Ryan and H. R. Bernard, "Techniques to identify themes," Field Methods, vol. 15, no. 1, pp. 85-109, 2003.

[28] I. Holmes and C. Potvin, Land Use Conflict and REDD+: Ideas for Designing an Inclusive Conflict Resolution Mechanism for REDD+, Lessons from the Ipetí-Emberá Community in Panama, McGill University, Montréal, Canada, 2012.

[29] A. Knox, C. Caron, A. Goldstein, and J. Miner, "The interface of land and natural resource tenure and climate change mitigation strategies: challenges and options," Paper prepared for the Expert Meeting on Land Tenure Issues for Implementing Climate Change Mitigation Policies in the AFOLU Sectors, Seattle, Wash, USA, Food and Agriculture Organization of the United Nations, November 2010.

[30] D. Mitchell, Land administration systems for climate mitigation payments, Paper prepared for the Expert Meeting on land tenure issues for implementing climate change mitigation policies in the AFOLU sectors by the Rural Development Institute, Seattle, Wash, USA, Food and Agriculture Organization of the United Nations, November 2010.

[31] S. Zbinden and D. R. Lee, "Paying for environmental services: an analysis of participation in costa Rica's PSA program," World Development, vol. 33, no. 2, pp. 255-272, 2005.

[32] T. K. Rudel and B. Horowitz, Tropical Deforestation: Small Farmers and Land Clearing in the Ecuadorian Amazon, Columbia University Press, New York, NY, USA, 1993.
[33] D. Kaimowitz, Livestock and Deforestation in Central America in the 1980s and 1990s, Center for International Forestry Research (CIFOR), Bogor, Indonesia, 1996.

[34] S. Humphries, "Milk cows, migrants, and land markets: unraveling the complexities of forest-to-pasture conversion in Northern Honduras," Economic Development and Cultural Change, vol. 47, no. 1, pp. 95-124, 1998.

[35] D. I. Stewart, After the Trees: Living on the Transamazon Highway, University of Texas Press, Austin, Tex, USA, 1994.

[36] S. B. Hecht, "The logic of livestock and deforestation in Amazonia," BioScience, vol. 43, no. 10, pp. 687-695, 1993.

[37] S. Wunder, "Can payments for environmental services reduce deforestation and forest degradation?" in ,Realising REDD+: National Strategy and Policy Options, A. Angelsen, M. Brockhaus, M. Kanninen, E. Sills, W. D. Sunderlin, and S. WertzKanounnikoff, Eds., pp. 213-224, Center for International Forestry Research (CIFOR) Bogor, Indonesia, 2009.

[38] C. Streck, "Rights and REDD+: legal and regulatory considerations," in Realising REDD+: National Strategy and Policy Options, A. Angelsen, M. Brockhaus, M. Kanninen, E. Sills, W. D. Sunderlin, and S. Wertz-Kanounnikoff, Eds., pp. 151-162, Center for International Forestry Research (CIFOR), Bogor, Indonesia, 2009.

[39] T. T. Pham, B. M. Campbell, S. Garnett, H. Aslin, and M. H. A. Hoang, "Importance and impacts of intermediary boundary organizations in facilitating payment for environmental services in Vietnam," Environmental Conservation, vol. 37, no. 1, pp. 64-72, 2010.

[40] A. Angelsen and D. Kaimowitz, Agricultural Technologies and Tropical Deforestation, CABI Publishing in association with CIFOR, Wallingford, UK, 2001.

[41] F. Montagnini and P. K. R. Nair, "Carbon sequestration: an underexploited environmental benefit of agroforestry systems," Agroforestry Systems, vol. 61-62, no. 1-3, pp. 281-295, 2004.

[42] F. Montagnini and C. Finney, "Payments for environmental services in latin America as a tool for restoration and rural development," Ambio, vol. 40, no. 3, pp. 285-297, 2011.

[43] L. Mannetje, L. Ramirez, M. Ibrahim, C. Sandoval, N. Ojeda, and $\mathrm{J} . \mathrm{Ku}$, "The importance of silvopastoral system in rural livelihoods to provide ecosystem services," in Proceedings of the 2nd International Symposium on Silvopastoral Systems, Universidad Autónoma de Yucatán, Mérida, Mexico, 2004.

[44] H. Neufeldt, A. Wilkes, R. Zomer et al., Trees on Farms: Tackling the Triple Challenge of Mitigation, Adaptation and Food Security, World Agroforestry Centre, World Agroforestry Centre Policy Brief 07, Nairobi, Kenya, 2009.

[45] A. Angelsen, C. Streck, L. Peskett, J. Brown, and C. Luttrell, "What is the right scale for REDD?" in Moving Ahead with REDD-Issues, Options and Implications, A. Angelsen, Ed., pp. 31-40, Center for International Forestry Research (CIFOR), Bogor, Indonesia, 2008.

[46] P. Pacheco, M. Aguilar-Støen, J. Börner, A. Etter, L. Putzel, and M. D. C. V. Diaz, "Landscape transformation in tropical Latin America: assessing trends and policy implications for REDD+," Forests, vol. 2, no. 1, pp. 1-29, 2010.

[47] WBI (World Bank Institute), "New training manual and workshops: estimating the opportunity costs of REDD+," WBI, Washington, DC, USA, 2008, http://wbi.worldbank .org/wbi/document/estimating-opportunity-costs-redd.

[48] N. H. Stern, The Economics of Climate Change: The Stern Review, Cambridge University Press, Cambridge, UK, 2007. 
[49] G. Kindermann, M. Obersteiner, B. Sohngen et al., "Global cost estimates of reducing carbon emissions through avoided deforestation," Proceedings of the National Academy of Sciences of the United States of America, vol. 105, no. 30, pp. 10302-10307, 2008.

[50] H. Gregersen, H. E. Lakany, A. Karsenty, and A. White, Does the Opportunity Cost Approach Indicate the Real Cost of REDD+?, Rights and Resources Initiative, Washington, DC, USA, 2010.

[51] L. Peskett and M. Brockhaus, "When REDD+ goes national: a review of realities, opportunities and challenges," in Realizing REDD+: National Strategy and Policy Options, A. Angelsen, Ed., pp. 25-44, Center for International Forestry Research (CIFOR), Bogor, Indonesia, 2009.

[52] WRI (World Resources Institute), "RPP Country Table: Panama," WRI, Panama City, Panama, 2009, http://www.wri.org/ publication/getting-ready.

[53] B. Blom, T. Sunderland, and D. Murdiyarso, "Getting REDD to work locally: lessons learned from integrated conservation and development projects," Environmental Science and Policy, vol. 13, no. 2, pp. 164-172, 2010.

[54] S. Wunder, Payments for Environmental Services: Some Nuts and Bolts, CIFOR, Bogor, Indonesia, 2005.

[55] D. Brown, F. Seymour, and L. Peskett, "How do we achieve REDD co-benefits and avoid doing harm?" in Moving Ahead with REDD-Issues, Options and Implications, A. Angelsen, Ed., Center for International Forestry Research (CIFOR), Bogor, Indonesia, 2008.

[56] O. Venter, W. F. Laurance, T. Iwamura, K. A. Wilson, R. A. Fuller, and H. P. Possingham, "Harnessing carbon payments to protect biodiversity," Science, vol. 326, no. 5958, p. 1368, 2009.

[57] B. Locatelli, V. Rojas, and Z. Salinas, "Impacts of payments for environmental services on local development in northern Costa Rica: a fuzzy multi-criteria analysis," Forest Policy and Economics, vol. 10, no. 5, pp. 275-285, 2008.

[58] A. Angelsen, Ed., Moving Ahead with REDD-Issues, Options and Implications Center for International Forestry Research (CIFOR), Bogor, Indonesia, 2008.

[59] E. Corbera, M. Estrada, and K. Brown, "Reducing greenhouse gas emissions from deforestation and forest degradation in developing countries: revisiting the assumptions," Climatic Change, vol. 100, no. 3, pp. 355-388, 2010.

[60] D. Kaimowitz and D. Sheil, "Conserving what and for whom? Why conservation should help meet basic human needs in the tropics," Biotropica, vol. 39, no. 5, pp. 567-574, 2007.

[61] E. F. Lambin and H. Geist, Eds., Land-Use and Land-Cover Change: Local Processes and Global Impacts, Springer, Berlin, Germany, 2006.

[62] T. K. Rudel, Tropical Forests: Regional Paths of Destruction and Regeneration in the Late Twentieth Century, Columbia University Press, New York, NY, USA, 2005.

[63] A. Fischer and L. Vasseur, "Smallholder perceptions of agroforestry projects in Panama," Agroforestry Systems, vol. 54, no. 2, pp. 103-113, 2002.

[64] G. A. Cerbu, B. M. Swallow, and D. Y. Thompson, "Locating REDD: a global survey and analysis of REDD readiness and demonstration activities," Environmental Science and Policy, vol. 14, no. 2, pp. 168-180, 2011.

[65] S. Caplow, P. Jagger, K. Lawlor, and E. Sills, "Evaluating land use and livelihood impacts of early forest carbon projects: lessons for learning about REDD+," Environmental Science and Policy, vol. 14, no. 2, pp. 152-167, 2011.
[66] S. Sloan, "Reforestation amidst deforestation: simultaneity and succession," Global Environmental Change, vol. 18, no. 3, pp. 425-441, 2008.

[67] J. R. Jones, Colonization and Environment: Land Settlement Projects in Central America, United Nations University Press, Tokyo, Japan, 1990.

[68] IADB (Inter-American Development Bank), "Panama: land administration and regularization project: loan proporal (PN0148)," IADB, Panama City, Panama, 2002, http://www. google.com.mx/url?sa $=\mathrm{t} \& \mathrm{rct}=\mathrm{j} \& \mathrm{q}=\& \mathrm{esrc}=\mathrm{s} \&$ source $=$ web \&cd $=1 \& v e d=0 \mathrm{CE} 0 \mathrm{QFjAA} \& u r l=\mathrm{http} \% 3 \mathrm{~A} \% 2 \mathrm{~F} \% 2 \mathrm{Fciteseerx}$.ist.psu .edu\%2Fviewdoc\%2Fdownload\%3Fdoi\%3D10.1.1.198. 683\% 26rep\%3Drep1\%26type\%3Dpdf\&ei=KWT_T5HEMuOi2wXa9siABA\&usg=AFQjCNG8uQ0ONQ4_DstWHaPAunTK4_xrpQ\&sig2=HocZ-VYjAdS6KvXZMETbIg.

[69] G. Ledec, The role of bank credit for cattle raising in financing tropical deforestation: an economic case study from Panama [Ph.D. thesis], University of California, Berkeley, Calif, USA, 1992.

[70] S. Heckadon Moreno, Cuando Se Acaban Los Montes, Editorial Universitaria and Smithsonian Tropical Research Institute, Panama City, Panama, 1983.

[71] H. Rosa, S. Kandel, and L. Dimas, "Compensation for environmental services and rural communities: lessons from the Americas," International Forestry Review, vol. 6, no. 2, pp. 187-194, 2004.

[72] M. C. Thompson, M. Baruah, and E. R. Carr, "Seeing REDD+ as a project of environmental governance," Environmental Science and Policy, vol. 14, no. 2, pp. 100-110, 2011.

[73] D. A. N. Brockington, J. I. M. Igoe, and K. A. I. SchmidtSoltau, "Conservation, human rights, and poverty reduction," Conservation Biology, vol. 20, no. 1, pp. 250-252, 2006.

[74] D. Brockington, Fortress Conservation: the Preservation of the Mkomazi Game Reserve, Tanzania, James Currey, Bloomington, Ind, USA, 2002.

[75] A. Agrawal and A. Angelsen, "Using community forest management to achieve REDD+ goals," in Realising REDD+: National Strategy and Policy Options, A. Angelsen, M. Brockhaus, M. Kanninen, E. Sills, W. D. Sunderlin, and S. WertzKanounnikoff, Eds., pp. 201-212, Center for International Forestry Research (CIFOR), Bogor, Ind, USA, 2009.

[76] L. R. Garcia-Amado, M. R. Perez, F. R. Escutia, S. B. Garcia, and E. C. Mejia, "Efficiency of Payments for Environmental Services: equity and additionality in a case study from a Biosphere Reserve in Chiapas, Mexico," Ecological Economics, vol. 70, no. 12, pp. 2361-2368, 2011.

[77] B. M. Campbell, "Beyond Copenhagen: REDD+, agriculture, adaptation strategies and poverty," Global Environmental Change, vol. 19, no. 4, pp. 397-399, 2009.

[78] L. Peskett, K. Schreckenberg, and J. Brown, "Institutional approaches for carbon financing in the forest sector: learning lessons for REDD+ from forest carbon projects in Uganda," Environmental Science and Policy, vol. 14, no. 2, pp. 216-229, 2011.

[79] S. Pagiola, "Payments for environmental services in Costa Rica," Munich Personal RePEc Archive (MPRA), no. 2010, 2006, http://ideas.repec.org/p/pra/mprapa/2010.html.

[80] S. Wunder and M. Albán, "Decentralized payments for environmental services: the cases of Pimampiro and PROFAFOR in Ecuador," Ecological Economics, vol. 65, no. 4, pp. 685-698, 2008. 
[81] CONAFOR (Comision Nacional Forestal), "Convocatoria 2011: programa para promover mecanismos de pago de servicios ambientales a través de Fondos Concurrentes," Secretaria de Medio Ambiente y Recursos Naturales (SEMARNAT), CONAFOR, Mexico City, Mexico, 2011.

[82] J. Pretty and H. Ward, "Social capital and the environment," World Development, vol. 29, no. 2, pp. 209-227, 2001.

[83] E. Ostrom, "Self-Governance and Forest Resources," Center for International Forestry Research (CIFOR), Occasional Paper No. 20, Bogor, Ind, USA, 1999.

[84] L. Tole, "Reforms from the ground up: a review of communitybased forest management in tropical developing countries (Environmental Management)," Environmental Management, vol. 45 , no. 6 , pp. 1312-1331, 2010.

[85] G. Brodnig, "Sharing benefits from carbon finance: lessons from the Guangxi CDM project," Social Development Notes, Social Dimensions of Climate Change, no. 121, 2009, http://documents.worldbank.org/curated/en/2009/12/ $11857142 /$ sharing-benefits-carbon-finance-lessons-guangxicdm-project.

[86] P. Weeks, J. Parckard, and M. Martinez-Velarde, "Cultural lenses and conservation biology: collaboration in tropical countries," in Protecting Biological Diversity: Roles and Responsibilities, C. Potvin, M. Kraenzel, and G. Seutin, Eds., McGill-Queen's University Press, Montreal, Canada, 2001. 

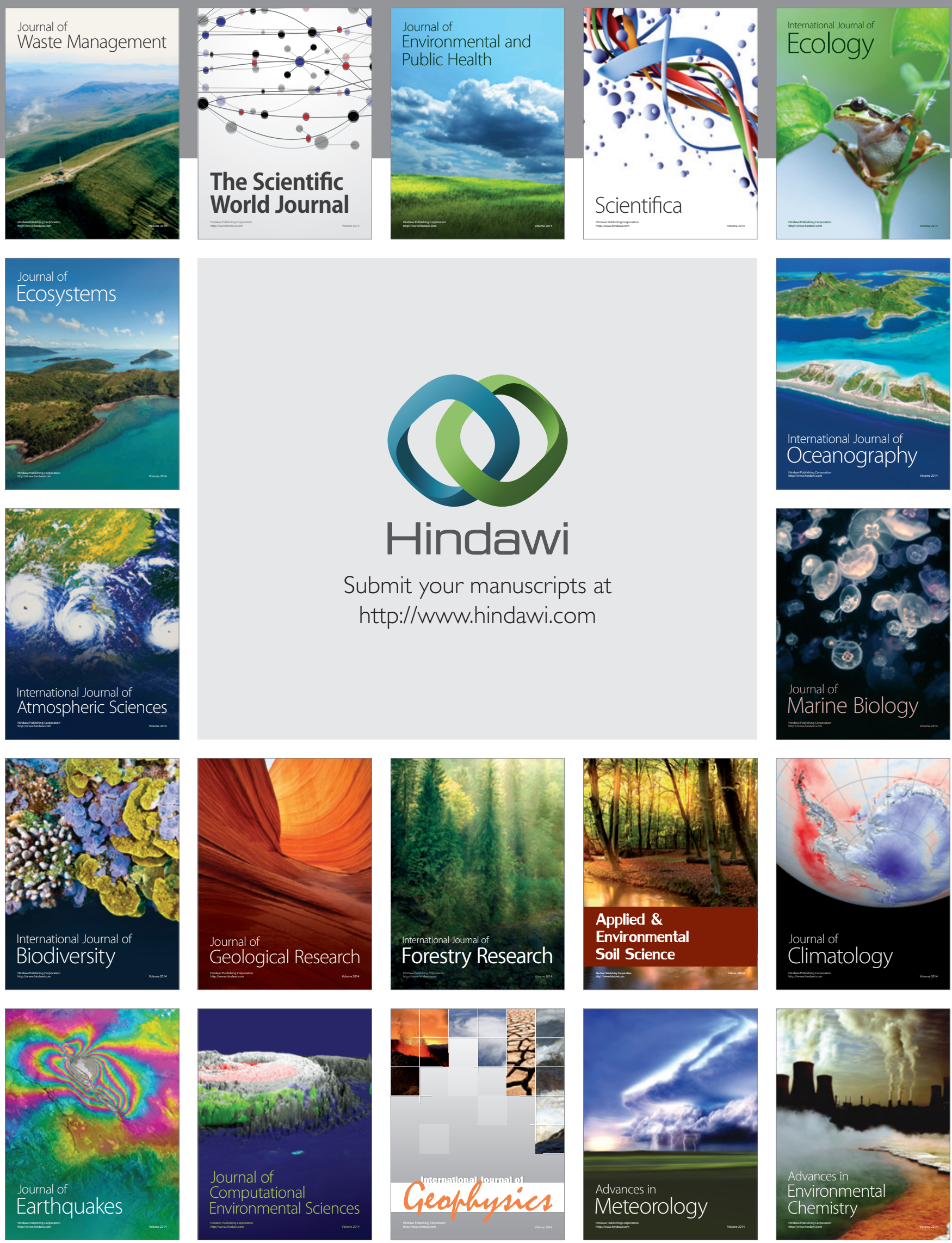